Free Speech 
This page intentionally left blank 


\section{Free Speech}

Ten Principles for a Connected World

Timothy Garton Ash

Yale

UNIVERSITY

PRESS

New Haven E London 


\section{Copyright (C) 2016 by Timothy Garton Ash.}

All rights reserved.

This book may not be reproduced, in whole or in part, including illustrations, in any form (beyond that copying permitted by Sections 107 and 108 of the

U.S. Copyright Law and except by reviewers for the public press), without written permission from the publishers.

The lyrics for Nina Simone's song 'I Wish I Knew How It Would Feel to Be Free', written by Billy Taylor and Dick Dallas, are quoted by permission. The lyrics for Eminem's song 'White America', written by Steven King, Jeffrey Bass, Luis Resto and Marshall Mathers, (c) published by Eight Mile Style LLC and Martin Affiliated LLC, administered by Kobalt Music Publishing Limited, are also quoted by permission.

Yale University Press books may be purchased in quantity for educational, business, or promotional use. For information, please e-mail sales.press@yale.edu (U.S. office) or sales@yaleup.co.uk (U.K. office).

Set in Electra and Trajan Pro types by Newgen.

Printed in the United States of America.

Library of Congress Control Number: 2015955529

ISBN 978-0-300-16116-8 (hardcover : alk. paper)

A catalogue record for this book is available from the British Library.

This paper meets the requirements of ANSI/NISO Z39.48-1992 (Permanence of Paper).

$$
10987654321
$$


To

All contributors to Free Speech Debate

freespeechdebate.com 
This page intentionally left blank 